\title{
The Digitalization of the Human Memory
}

\author{
Rommel B de la Cruz* \\ Professor, Jose Rizal University, Philippines, USA
}

Submission: December 11, 2018; Published: January 16, 2019

*Corresponding author: Rommel B de la Cruz, Professor, Jose Rizal University, Unit C Reyes St. Mandaluyong, Philippines, USA

\section{Opinion}

The pace that Information and Communication Technologies (ICTs) have evolved and revolutionized the society maroons human memory in a tumultuous sea of change, unpredictable and unstable. The future has been yanked out from its temporal location, dragging it into our perception of the present. Just days ago, they were saying, "The future has arrived." Actually since the time ICTs were put into motion, the future as we know it is already around us. It has been here for all we know, complicating the present and obscuring the liens of past and present.

Robert Hassan in his book Media, Politics, and the Network Society [1] presents some compelling argument how ICTs are affecting the human memory. He cites equally insightful views which are also quoted in this article. Our memory is instrumental in humanizing the species that has emerged as the most dominant of the other sentient living things in the planet. A sui generis. Memory is the mirror of our being close to God's likeness. It preserves the concepts, beliefs, and experiences that we value. With ICTs ruthless conquest and subjugation of the various spheres of human activity - with ourselves as more than willing accomplice, Hassan thinks that we are being changed into beings that think and behave the way digital memory program does.

A parvenu strolling nonchalantly in a busy street in Makati is all sucked in into his I-phone - casually looking on the reduced screen image of a person speaking, hastily tuning in without really listening to some downloaded songs, and cursorily reading the messages then replying with templates or emojis. At work in between his ICT-related or -mediated actions, he does these over and over again with interminable internet surfing, chatting, gaming, and movie or TV program glancing. At night before he hits the hay, he will do any of these activities again, perhaps in different ICT medium, like on his laptop, tablet, or smart TV.

Actually, even before he shuts his eyes to descend into some subconscious abyss, this half-asleep individual will plan out through his PDA the things he will have to be concerned tomorrow. He does this maybe to anticipate a problem or create situation that gives him access to financial proposition. The future has not only arrived for him. It is all in his mind. ITCs have digitalized his mind to live the future through the present.
Everything now has to be in the express lane of the ICTs. It is fast. It has to catch the future - the changes in work, entertainment, and society in general. There is no recollection. Only the present being compressed by the waves rushing onto the shore of battered present. James Gleick, who authored an influential book The Acceleration of Just About Everything [2] describes this condition in his work. Everything new, may it be a new product to be released in the market or idea to be circulated, turns old in just a few moments. Paul Virilio in writing Information Bomb [3] observes this happening. With him seeing ICTs inveterately opening up and seeping into every cranny and nook of the human memory, Virilio calls what is happening at large the "acceleration of reality."

At the forefront of the ICTs revolution is the internet. Manuel Castells in his book The Internet Galaxy [4] compares the role of the internet to electricity. While electricity created and propelled the industrial age into the 20th century, internet has informationalized the contemporary society, creating for it a denizen in temporal and virtual dimension. Knowledge has become timeless. New and old ideas intersect, affecting and changing the present context of the use of knowledge. The age of published information is swept under the rug of ICTs.

With our human memory being digitalized, what will happen to us? Zygmunt Bauman, who wrote Globalization [5], a book that examines critically our present borderless world, is cynical on the effects of ICTs. For him, the ICTs fashion out a society uncritical about what it has become and will become. David Shenk in his book Data Smog [6] describes it a "memory loss" because of information overload. He laments that people cannot filter information anymore by appreciating some while criticizing others. ICTs create an environment where we do not have to think anymore according to our beliefs, values, and culture. A corporate chief in an information technology company may have justified this warping of time by equating time to money. Indeed, this may have inspired the existence of this environment. The faster it becomes the more money it generates.

This environment has become a mirror image of the human memory. It is a digitalized memory. It lacks a narrative. It lacks appreciation of the simple and innocent things in life. In this memory we become less than human. We love less. We 
celebrate less. We cry less. The novel Slowness aptly puts how this environment has become when it says, "The degree of speed is directly proportional to the intensity of forgetting." If we are not going to question ourselves soon enough, in the very near future our memory may cease to remember who we really are [7].

\section{References}

1. Hassan Robert (2004) Media, Politics, and the Network Society. Open University Press: United Kingdom.

2. Gleick James (1999) The Acceleration of Just About Everything. Beverly Hall: New York, United States.

This work is licensed under Creative Commons Attribution 4.0 License DOI: 10.19080/GJIDD.2019.06.555676
3. Virilio Paul (2000) The information bomb. UK: Verso Books, United Kingdom.

4. Castells Manuel (2001) The Internet Galaxy. Oxford University Press, United Kingdom.

5. Bauman Zygmunt (1998) Globalization: The Human Consequences. Blackwell Publishers, Ltd: United Kingdom.

6. Shenk David (1997) Data Smog. Harper Collins Publishers: New York, United States.

7. Kundera Milan (1995) Slowness. Harper Collins Publishers: New York, United States.

\section{Your next submission with Juniper Publishers} will reach you the below assets

- Quality Editorial service

- Swift Peer Review

- Reprints availability

- E-prints Service

- Manuscript Podcast for convenient understanding

- Global attainment for your research

- Manuscript accessibility in different formats ( Pdf, E-pub, Full Text, Audio)

- Unceasing customer service

Track the below URL for one-step submission https://juniperpublishers.com/online-submission.php 